\title{
The Effect of Tax Fairness, Tax Socialization and Tax Understanding on Tax Compliance: A Study on Micro, Small and Medium Enterprises (MSMEs)
}

\author{
Sizka Rismaningsih Lestary \\ Faculty of Economics and Business \\ Universitas Padjadjaran \\ Memed Sueb \\ Faculty of Economics and Business \\ Universitas Padjadjaran \\ Ivan Yudianto \\ Faculty of Economics and Business \\ Universitas Padjadjaran
}

\begin{abstract}
This research aims to identify the effect of fairness, socialisation and understanding on the Micro Small Medium Enterprises (MSMEs) taxpayer compliance towards Government Regulation number 23/2018 regarding income tax from business received or accrued by taxpayers who have certain gross turnover. This research used a quantitative approach, and data were collected using the Likert scale questionnaire. In this research, the population was 283 MSMEs actors registered at the Cooperatives and Small and Medium Enterprises Office, Bandung. The sampling method used was purposive sampling. The data analysis technique used in this research is path analysis. Based on the partial test on the first regression model hypothesis, tax fairness and tax socialisation are positively and significantly associated with the tax understanding. The second regression model hypothesis's partial test indicates that tax fairness does not affect, while the taxation socialisation and understanding of taxation positively affect MSME taxpayers' compliance.
\end{abstract}

Keywords: Tax Fairness; Tax Socialization; Tax Understanding; Taxpayer Compliance

\section{Introduction}

Micro, small and medium-sized enterprises (MSMEs) dominate Indonesia's economy in recent years. The Ministry of Cooperatives and Small and Medium Enterprises provided information that the number of MSMEs in Indonesia has risen by about 2.5 million new MSMEs between 2016 and 2018. One of the efforts to be achieved in developing MSMEs is the contribution of MSMEs to GDP. The Ministry of Cooperatives and SMEs stated that 60 per cent of MSMEs contribute to the GDP in 2017. Moreover, the MSMEs sector absorbed 97 per cent of the workforce. The private sector contributes to income tax, one of which comes from the micro, small and medium-sized enterprises. However, in 2017, the total payment of MSMEs net income to the income tax paid by the taxpayer only contributed 2.2 per cent (Directorate General of Taxation, 2019).

The government's initial measure in raising taxes in the MSMEs sector began with the enactment of Government Regulation Number $46 / 2013$, by setting a final MSMEs tax rate of $1 \%$ for corporate and individual group taxpayers who have income with a total turnover of less than 4.8 Billion in a year. With the enactment of Government Regulation Number 46/2013, the 
degree of taxpayers compliance was still poor and had not yet reached the revenue target (Ayu et al., 2015). The distribution of MSMEs final net income payments when Net Income Number 46 was already in place in 2013 revealed three provinces in Java Island with the highest contribution to the final income tax contribution

Table 1. Distribution of MSMEs Income Tax Payments in 2017

\begin{tabular}{ccc}
\hline No & Province & Total (in Billion Rp) \\
\hline 1. & West Java & 775,6 \\
2. & East Java & 764,8 \\
3. & Central Java & 510,9 \\
\hline
\end{tabular}

Among the three provinces in Java, West Java is the province with the highest number of MSMEs final income tax payments in 2017 compared to East Java and Central Java. Micro and Small Enterprises dominate the main corporation in West Java. From the 2016 Advanced Economic Census results conducted by the Central Bureau of Statistics (BPS), the number of businesses in West Java reached more than 4.5 million firms or 98.84 per cent of the overall non-agricultural businesses in West Java. This business will also absorb to as many as 9.7 million workers or around 74.07 per cent of the total non-agricultural workforce in West Java (Central Bureau of Statistics, 2018).

The level of compliance and awareness among MSMEs actors is still low. One factor that results in a lack of awareness is taxpayers being closed-minded and their perception, which still appear to be negative/pessimistic (Susanto, 2019). Previously, the 1 per cent tariff for MSMEs in Indonesia referred to Government Regulation number 46/2013. A review of Government Regulation number 46/2013 for small entrepreneurs with incomes below 4.8 billion for entrepreneurs who complained about the tax base of gross income, because the gross turnover has been equal or even less than the profit they earn (Yusdita, 2017).

Taxpayer compliance can be affected by various factors. One of the non-economic variables that affect taxpayer compliance is fairness (Gilligan \& Richardson, 2005). There are two alternatives to tax fairness: the benefit principle, namely that the tax scheme is deemed equal when the participation paid is following the benefits received. The second one is the abilityto-pay principle, namely the tax scheme is deemed to be fair if the tax is only interpreted from the side of the taxation regardless of the expenditure side, where everyone has to pay for expenses made by the government according to their respective abilities to pay (Musgrave \& Musgrave, 1989). The principle of economic sacrifice drives taxpayer compliance in paying taxes. Taxpayers expect direct returns when paying taxes, such as public services and infrastructure built by the government (Mangoting \& Ganis, 2015).

Government Regulation Number $46 / 2013$ is considered to have several weaknesses in regulation and is not under the principle of justice (fairness). According to Mansury (1996), Government Regulation Number 46/2013 based on the concept of justice does not reflect the ability to pay. Fair taxation is that the greater the income, the greater the tax to be paid (vertical equity). Here, income is referred to the net income after deducting the costs of deducting the gross income permitted in the statutory provisions. Previously, it was presumed in Government Regulation Number 46/2013 that every business carried out was profitable. Many small businesses made sales only to rotate their supplies without any profit (Endrianto, 2015). Also, uncertain market conditions affect the selling power and purchasing power of consumers. Therefore, the 1 per cent tariff is perceived to be very burdensome, particularly for businesses at risk of loss, as it can directly impact business continuity.

In July 2018, Government Regulation Number 23/2018 was issued concerning reducing 
the tariff for MSMEs by $0.5 \%$. Government Regulation Number 23 /2018, which took effect as of July 1, 2018, is valid to replace the previous Government Regulation, namely Government Regulation number 46/2013 which provides a reduction in income tax rates for MSMEs from $1 \%$ to $0.5 \%$. It is intended to motivate community participation in economic activities so that in the future, it can provide convenience and justice when carrying out obligations for MSMEs. Government Regulation number 23/2018 is a relatively new government policy. This policy is one of the fiscal facilities for income tax incentives intended for MSMEs players to encourage the potential for final income tax revenue from the MSMEs sector, but tax revenue may decrease in the short term.

Within this Government Regulation No 23, taxpayers must know several matters, including the tax options that the taxpayer may select, whether to follow Government Regulation No 23 or Article 17 of the Income Tax Law. In
Article 3 paragraph (2) it is explained that if the taxpayer has chosen to be subject to Income Tax based on Article 17 of the Income Tax Law, the taxpayer can no longer reuse the $0.5 \%$ tariff. Therefore, choosing the use of the $0.5 \%$ tariff must be carefully considered through financial or tax administration considerations. It certainly requires socialisation from the Tax Service Office so that taxpayers may obtain an adequate understanding upon the contents of the obligations of Government Regulation number 23/2018. If the public does not understand the tax provisions, taxpayers may perceive the income tax unjust (Mei Tan \& Chin-Fatt, 2000).

Based on the 2016 Advanced Economic Census, it is said that the city of Bandung is one of the largest MSMEs contributors in West Java. However, there is a drastic decline in the tax revenue in Bandung after the enactment of Government Regulation Number 23/2018. The following shows the data of tax revenue in Bandung from 2016 to 2019.

Table 2. Tax Revenue of MSMEs in Bandung

\begin{tabular}{lcccc}
\hline \multicolumn{1}{c}{ Work Unit } & $\mathbf{2 0 1 6}$ & $\mathbf{2 0 1 7}$ & $\mathbf{2 0 1 8}$ & $\mathbf{2 0 1 9}$ \\
\hline \multicolumn{1}{c}{ Tax Service Office } & Total Payment & Total Payment & Total Payment & Total Payment \\
Bandung Tegallega & 58.479 .140 .753 & 75.410 .462 .256 & 87.322 .213 .579 & 47.996 .954 .212 \\
\hline Bandung Cibeunying & 68.761 .688 .435 & 98.859 .059 .765 & 112.254 .038 .992 & 28.727 .080 .753 \\
\hline Bandung Karees & 65.194 .375 .132 & 68.600 .495 .601 & 83.103 .516 .558 & 32.109 .889 .424 \\
Bandung Bojonagara & 66.043 .931 .169 & 82.594 .834 .372 & 96.665 .078 .454 & 33.147 .046 .957 \\
\hline Bandung Cicadas & 23.930 .857 .198 & 29.129 .597 .602 & 28.761 .557 .971 & 17.382 .221 .611 \\
\hline
\end{tabular}

There was a decrease in tax revenue from 2018 to 2019 . While the tariff was reduced by $0.5 \%$ in the event of a rise in taxpayers' number, it was possible to retain tax collections by recruiting additional taxpayers. Taxpayers can be more compliant if their understanding of taxation increases (Putra, 2020). Not all MSMEs taxpayers know and understand the provisions stipulated in Government Regulation number 23 of 2018, so much socialisation is needed (Yudha \& Dewi, 2018). Some MSMEs actors who already have business licenses and Tax ID number admit that they do not know and understand the provisions stipulated in Government Regulation No 23, they claim to know about tariff changes but do not know the contents of other provisions regulated therein (Ningsih et al., 2020).

At the beginning of the issuance of Government Regulation No 23, several Tax Service Office in Bandung had conducted outreach activities for eight days starting from July 16 to July 25, 2018. In implementing the Government Regulation No 23, many MSMEs still do not know the information, so the Tax Directorate General needs to conduct intense socialisation (Indriana \& Moh, 2020). Taxpayers are aware of the latest rates, but taxpayers are also uncertain of this regulation's time (Rahmawati \& Irianto, 2019). To increase taxpayers' growth and encourage the contribution of state revenue, especially tax revenue in Bandung City from the 
MSMEs sector, this research was conducted to discuss taxpayer compliance towards government regulation number 23 of 2018.

\section{Literature Review}

\section{Attribution Theory}

Heider (1958) in his writing entitled "Native Theory of Action", has developed attribution theory, which is a conceptual framework for a person to use to translate, describe and predict one's behaviour. Attribution theory developed by Heider and Weiner explains that this theory examines how a person concludes the triggers of behaviour, which the behaviour comes from himself or other people (organisations). Another definition states that attribution theory is an experiment to determine whether an individual's behaviour is caused by internal or external factors (Robbins, 2015).

\section{Planned Behaviour Theory}

One of the theories in the field of psychology regarding the factors that influence tax compliance, one of which is through the Theory of Planned Behavior (TPB). TPB model is used to assess behaviour that does not comply with tax regulations. According to (Ajzen, 1985), the TBP Model explains that a person's influence to be disobedient to tax regulations can be caused by the individual him/herself to be disobedient. Three factors influence individual behavioural intentions, namely 1) Behavioural belief, 2) Normative belief and control belief. Behavioural belief is a feeling of confidence from the results of a behaviour (outcome belief) then there is an evaluation or assessment as the results of such behaviour. Normative belief refers to a person's feeling of confidence in others' normative expectations on which he is based. Meanwhile, control belief is associated with a person's feeling of confidence about a situation that hinders or supports his/her actions.

\section{Taxpayer Compliance}

Taxpayer compliance can be interpreted as a situation where taxpayers are willing to complete all their tax obligations and rights (Nurmantu, 2005). According to Nurmantu (2015), taxpayer compliance is categorised into two categories; 1 ) formal compliance and 2) material compliance. Formal compliance is the condition in which the taxpayer fulfils all of its formal obligations as stipulated in the tax law. Meanwhile, material compliance refers to the condition in which the taxpayer fulfils all material provisions regarding taxation based on the contents of the law.

\section{Tax Fairness Concept}

According to (Musgrave \& Musgrave, 1989) the approach to tax fairness is divided into two, namely 1) The benefit principle and 2) The ability-to-pay principle. The benefit principle refers to the tax system categorised as fair if the taxpayer's participation is proportional to the government's services' benefits. Meanwhile, The ability-to-pay principle is a tax system that is only seen from the taxation side regardless of the expenditure side, where everyone must pay for expenses made by the government according to their respective abilities to pay.

\section{Tax Socialisation}

Referring to the circular letter of the DirectorGeneral of Taxes Number: SE-98/PJ/2011, Tax socialisation is an effort and procedure to channel various information about taxation in order to create knowledge, skilled attitudes and public behaviour both in the business world, apparatuses and government and non-governmental organisations to be motivated to understand, care, be aware of and contribute to fulfilling tax obligations.

\section{Tax Understanding}

Knowledge and understanding referred to the understanding of general provisions and tax procedures which include how to submit tax returns, make payments, places to make payments as well as fines and deadlines for tax return payments and reporting (Resmi, 2019) 


\section{The Effect of Tax Fairness on MSMEs Tax Compliance}

Government Regulation Number 23/2018 is a policy that provides incentives to taxpayers by reducing the final income tax rate by $0.5 \%$. The previous $1 \%$ tariff in Government Regulation 46 was still considered unfair for MSMEs (Ayu et al., 2015). According to Musimenta et al. (2017), tax fairness affects taxpayer compliance. Justice in taxation is viewed from the ability to pay for each taxpayer and the benefits received by taxpayers from paying taxes or the benefit principle (Musgrave \& Musgrave, 1989). Mangoting \& Ganis (2015), in their research, also revealed that fairness is affected by the benefits provided by the government to taxpayers for returns or rewards after paying taxes.

Hypothesis 1: there is a positive and significant effect of tax fairness on MSMEs tax compliance

\section{The Effect of Tax Socialization on MSMEs Tax Compliance}

Government Regulation number 23/2018 has replaced the previous regulation, namely Government Regulation number 46/2013. The research conducted by Syaputra (2019) stated that the relationship between taxpayers' perceptions of Government Regulation 23 with MSMEs taxpayer compliance could not be strengthened by tax socialisation as it lacks tax dissemination. Hendri (2018), Putra \& BBN (2020) in their research, stated that the implementation of Government Regulation 23 socialisation by Tax Services Office has a significant effect on the compliance of MSMEs taxpayers. Therefore, the socialisation regarding Government Regulation number 23/2018 is deemed necessary.

Hypothesis 2: there is a positive and significant effect of tax socialisation on MSMEs tax compliance.

\section{The Effect of Tax Understanding on MSMEs Tax Compliance}

One of the factors that affect MSMEs taxpayers' compliance is their understanding of taxation rules (Putra \& BBN, 2020). Understanding taxation does not just understand general provisions and tax procedures but also understanding how to fill out a tax return, calculate taxes and report tax return on time (Resmi, 2019). The government policy regarding Government Regulation number 23/2018 is counted as a new policy, where Government Regulation No 23 is optional. Taxpayers can choose to use it or choose the tariff scheme as regulated in Article 17 of Law Number 36/2008 concerning Income Tax. Putra (2020), Z.A \& Mayowan (2016), Febri \& Sulistiyani (2018) in their research, stated that the understanding of taxation has a significant effect in influencing the compliance of MSME taxpayers.

Hypothesis 3: There is a positive and significant effect of understanding taxation on MSMEs tax compliance

\section{The Effect of Tax Fairness on MSMEs Tax Understanding}

According to Gilligan \& Richardson (2005), one of the critical non-economic factors influencing taxpayers to comply is justice. Tax fairness can affect taxpayers' understanding because it will reduce the taxation system's uncertainty and reduce misunderstandings in a taxation system (Mei Tan \& Chin-Fatt, 2000). According to previous research conducted by Zulhaj et al. (2016), Mei Tan \& Chin-Fatt (2000), Syaputra (2019) stated that tax fairness has a significant effect in supporting taxpayer compliance.

Hypothesis 4: There is a positive and significant effect of tax fairness on Tax understanding.

The Effect of Tax Socialization on MSMEs Tax Understanding

One of the factors that influence the understanding of taxation is the information factor. Information obtained is in the form of counselling and through mass media (Notoatmodjo, 2003). One factor influencing MSMEs taxpayer compliance is taxpayers' knowledge (Putra \& BBN, 2020). The more taxpayers understand their obligations, the more they will increase their tax obligations (Putu \& 
Cahyani, 2019). To increase understanding and knowledge of Government Regulation No 23, more socialisation is needed by Tax Sevices Offices. According to previous research conducted by Yudha \& Dewi (2018), Suci et al., (2019), Putri \& Nurhasanah (2019), Putra (2020), that tax socialisation has a significant effect on the knowledge of MSME taxpayers.

Hypothesis 5: there is a positive and significant influence of taxation socialisation on tax understanding

\section{The Effect of Tax Fairness on MSMEs Tax Compliance through Tax Understanding}

One of the reasons for this reduction in tariffs is justice in Government Regulation number 23 of 2018. The previous rate was unfair because of taxes' imposition on different taxpayers' turnover (Ayu et al., 2015). Musgrave \& Musgrave (1989) defined tax fairness as two aspects of assessing fairness in taxes: taxpayers' ability to pay and secondly the benefits of paying taxes. The terms of justice, namely in the tax collection law, it must be fair and equitable according to their respective abilities (Endrianto, 2015). However, before measuring whether a regulation is fair or not, taxpayers are expected to understand their obligations and rights in using the facilities in Government Regulation number 23 of 2018. Arviana (2018) argues that taxpayers' justice and understanding are two variables that influence taxpayer compliance. Tax justice begins with tax knowledge about tax regulations, which will give taxpayers confidence whether the policy is considered fair or not (Musimenta et al., 2017).

Hypothesis 6: there is a positive and significant effect of tax justice on MSMEs tax compliance through Tax understanding

The Effect of Tax Socialization on MSMEs Tax Compliance through Tax Understanding
Tax socialisation is an effort made by the Tax Directorate General to distribute information or counselling to taxpayers which contain the knowledge of tax regulations and procedures to understand and be aware of their tax obligations. According to Widodo (2010), several tax socialisation indicators, among others, are where the socialisation has the media to convey it, either directly or through mass media. The socialisation that is delivered must also be in a way that is easy to understand and understand (Mahadianto \& Astuti, 2017). According to Syaputra (2019), the taxpayer's understanding of Government Regulation 23 positively affects MSMEs taxpayer compliance. In line with research (Arviana, 2018), the understanding of taxation affects taxpayer compliance. Such understanding has resulted from socialisation (Yudha \& Dewi, 2018). The variable understanding of taxation can mediate taxation on tax compliance (Hadiz \& Saryadi, 2018).

Hypothesis 7: there is a positive and significant effect of tax socialisation on MSMEs tax compliance through Tax understanding

\section{The method, Data and Analysis}

This research is descriptive research with a quantitative approach. Sugiyono (2018) explained that the purpose of descriptive research is to describe what is studied, in the form of objects that will be seen through existing data in the form of samples and populations as they are, without making general conclusions. The sample in this research is 283 MSMEs members registered at the Cooperative and SME Office which were taken by purposive sampling method with the following criteria: (1) MSMEs are registered and own Tax ID, (2) MSMEs that use final taxes based on Government Regulation number 23 of 2018. Each operational variable definition is described in table 3 .

Table 3. Variable Operationalisation

\begin{tabular}{|c|c|c|}
\hline Variable & Definition & Indicator \\
\hline $\begin{array}{l}\text { Tax Fairness (X1) } \\
\text { (Musgrave \& } \\
\text { Musgrave, 1989) }\end{array}$ & $\begin{array}{l}\text { Fairness in taxation means that the state cannot } \\
\text { differentiate between its citizens. Taxpayers who }\end{array}$ & $\begin{array}{l}\text { 1. Benefit principle } \\
\text { 2. ability-to-pay principle }\end{array}$ \\
\hline
\end{tabular}


fulfil their obligations in paying taxes must be in balance between their income and their abilities

Tax Socialisation

(X2)

SE-22/PJ/2007

concerning

Uniformity

Taxation

Socialization for the

Community

Tax Understanding

(Z)

Rahayu (2010)

Taxpayer

Compliance (Y)

Nurmantu (2015)
Tax socialisation is an effort and procedure to channel various information about taxation in order to create knowledge, skilful attitudes and behaviour of the community both in the business

of world, apparatus as well as government and nongovernment agencies to be motivated to understand, care, be aware and contribute to fulfilling tax obligations.

Understanding in taxation is knowing and understanding tax rules, meaning that taxpayers who are in the process of understanding and then applying their knowledge to make tax payments Compliant taxpayers can be interpreted as a situation where taxpayers want to complete all their tax obligations and rights
1. Information Media

2. Slogan

3. Method of Delivery

4. Quality of information sources

5. Socialisation materials

6. Extension activities

1. General provisions \& procedures for taxation

2. Knowledge of the tax system

3. Knowledge of tax function

1. Understand the provisions of the Taxation Law

2. Fill out the tax return completely and clearly

3. Pay and report taxes on time

4. Calculating the tax payable correctly

\section{Data Collection Technique}

Data were collected using a Likert scale questionnaire with a score of 1-5. The Likert scale model where 1 (one) refers to disagree strongly and 5 (five) refers to strongly agreeing. Questionnaires were distributed via an electronic platform to respondents, namely all the MSMEs registered at the Cooperative and SMEs department of Bandung City.

\section{Path Analysis}

The current research uses path analysis as the method of analysis. Path analysis is a development of regression analysis, and path analysis can describe and test the relationship between variables and models in the form of cause and effect between variables (Sugiyono,
2019). Through path analysis, there are exogenous (independent) variables and endogenous (dependent) variables. Using path analysis, the fastest and shortest path will be found for an independent variable that leads to the last dependent variable.

\section{Research Results and Discussion}

\section{Hypothesis Testing for the First Regression Model}

The first regression model equation is conducted to test the effect of the independent variable, namely tax justice (X1) and tax socialisation (X2) on the intervening variable, namely tax understanding $(\mathrm{Z})$. The regression results for the first structural estimation equation are presented in the following table.

Table 4. Coefficient of Determination (R2) Regression Model I

\begin{tabular}{|l|l|l|l|l|}
\hline Model & $\mathrm{R}$ & R Square & Adjusted R Square & Std. Error of the Estimate \\
\hline 1 & $.357^{\mathrm{a}}$ & .127 & .121 & 324.798 .879 \\
\hline
\end{tabular}

a. Predictors: (Constant), X2, X1

Based on the test results in table 4, it is known that the adjusted $\mathrm{R}$ Square value is 0.121 , which means that tax fairness (X1) and tax socialisation (X2) affects Tax Understanding variable (Z) by 
$21.1 \%$ while other variables outside of this research influence the remaining $71.9 \%$. Table 5 shows how the independent variable partially affects the understanding of taxation $(\mathrm{Z})$. details can be seen in the table as follows.

Table 5. Statistical Test Results for Regression Model I

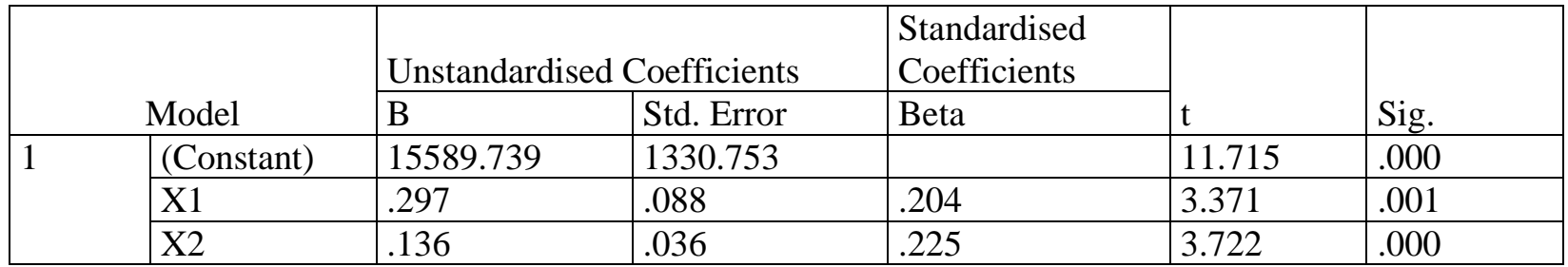

a. Dependent Variable: $\mathrm{Z}$

Based on the test results in table 5, each independent variables affect the dependent variable. The tax justice variable (X1) has a path coefficient value of 0.204 , which is positive and a sig value $t=0.001$. It can be concluded that the tax justice variable (X1) has a positive and significant effect on the tax understanding variable $(\mathrm{Z})$. The tax socialization variable (X2) has a path coefficient value of 0.225 , positive and sig.t $=0,000$. It can be concluded that the tax socialisation variable (X2) has a positive and significant effect on tax understanding variable
(Z). First Structural Model Regression Equation formulated $\mathrm{Z}=0,204 \mathrm{X} 1+0,225 \mathrm{X} 2+0,873$ Hypothesis Testing for the Second Regression
Model

The second regression model test was conducted to test the independent variable's effect on the dependent variable by including the understanding of taxation $(\mathrm{Z})$ as an intervening variable. The regression results for the second structural estimation equation are presented in the following table 6 .

Table 6 Results of the Determination (R2) of the Hypothesis of the Second Regression Model

\begin{tabular}{|l|l|l|l|l|}
\hline Model & R & R Square & Adjusted R Square & Std. Error of the Estimate \\
\hline 1 & $.467^{\mathrm{a}}$ & .218 & .210 & 2326.66727 \\
\hline
\end{tabular}

a. Predictors: (Constant), Z, X1, X2)

Based on the test results in the table above, it is known that the adjusted $\mathrm{R}$ Square value is 0.210 which means that the tax justice variable (X1), tax socialisation $(\mathrm{X} 2)$ and tax understanding $(\mathrm{Z})$ can influence the taxpayer compliance variable (Y) by
$21 \%$ while $79 \%$ the rest is influenced by other variables outside of this study. The table below will show how tax fairness (X1), tax socialisation (X2) and understanding of taxation (Z) partially affect taxpayer compliance (Y).

Table 7. Hypothesis Statistical Test Results for the Second Regression Model

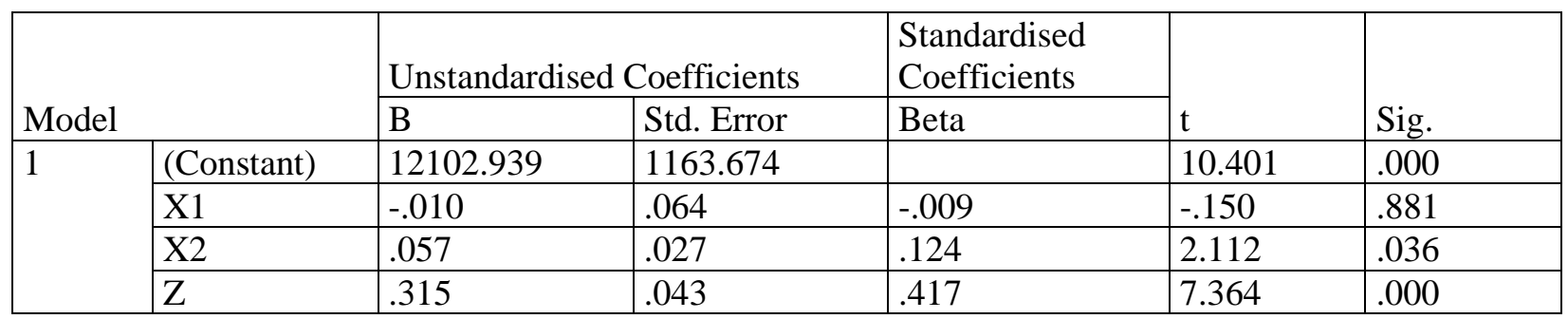

a. Dependent Variable: Y 
Based on the test results in the table above, the effect of each independent variable partially on the dependent variable can be interpreted as follows:

a. The tax fairness variable (X1) has a path coefficient of -0.009 , which is negative and a sig t value. $=0.881$ greater than $\alpha=0.05$, which means insignificant, it can be concluded that partially the tax justice variable (X1) has a negative and insignificant effect on taxpayer compliance.

b. The tax socialisation variable (X2) has a path coefficient value of 0.124 which is positive and the sig.t $=0.036$ value is smaller than $\alpha=$ 0.05 which means significant, so it can be concluded that partially, the tax socialisation variable (X2) has a positive effect and significant to taxpayer compliance $(\mathrm{Y})$

c. The tax understanding variable $(\mathrm{Z})$ has a regression value of 0.147 which is positive and sig.t $=0,000$ is smaller than $\alpha=0.05$ which means significant, it can be concluded that partially, the tax understanding variable has a positive and significant effect on the taxpayer compliance variable $(\mathrm{Y})$

Second Structural Model Regression Equation, $Y$ $=-0,009 X 1+0,124 X 2+0,417 \mathrm{Z}+0,782$. The beta path coefficient values from the results of the first and second structural path analysis tests and the error $(\varepsilon 1$ and $\varepsilon 2)$ can be described in the path diagram, as shown in Figure 1.

Figure 1 Path Diagram

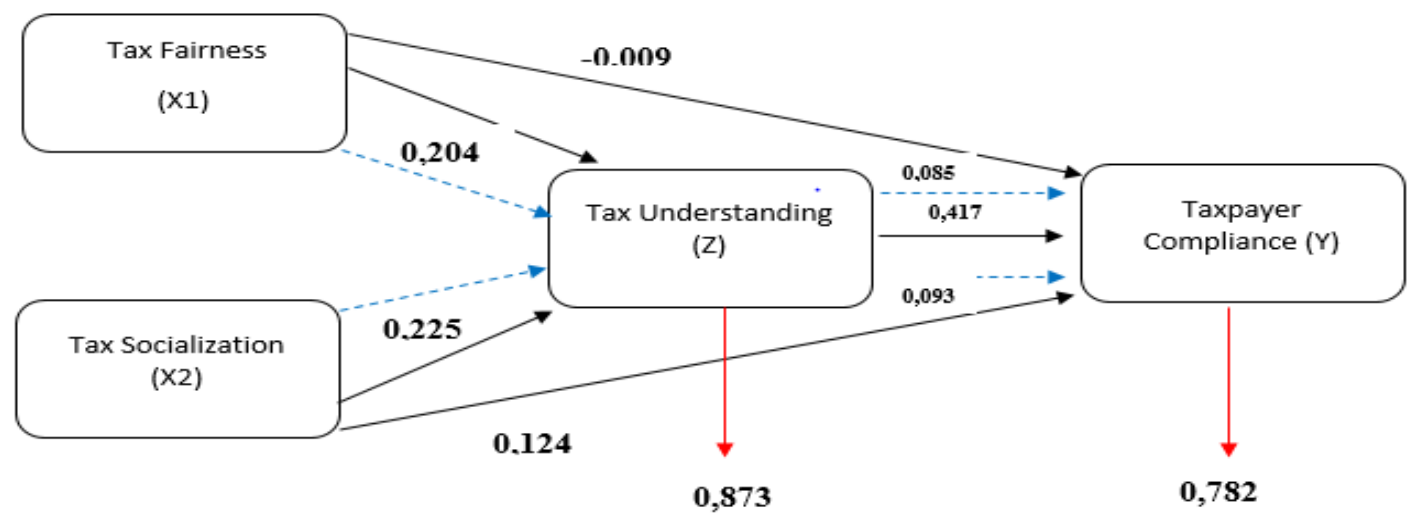

Note:

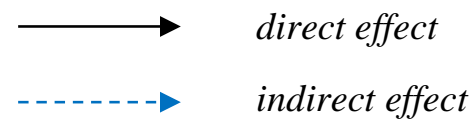

\section{Tax Fairness and Taxpayer Compliance}

The test results with the t-test obtained results with a significance level of the tax justice variable of 0.881 and a regression coefficient of -0.009 . It proves that there is no influence between tax justice on the compliance of MSME taxpayers in Bandung; it can be identified from the significance value of $0.881>0.05$. It means that the significant value obtained from the tax justice variable is greater than 0.05 . This study's results are in line with Sella \& Pusposari (2018) research that there is no positive influence between justice and the willingness to obey MSMEs. Previous research conducted by Christensen (1994) stated that the variable of justice is difficult to measure because of four factors, namely: dimensional problems, a society that is measured in size, complexity and a lack of justice. 


\section{Taxa Socialization and Tax Compliance}

The results of the t-test showed that the level of significance of the tax socialisation variable was 0.036 , which was smaller than $\alpha=0.05$, and the regression coefficient was 0.057 . It proves a positive and significant influence between taxation's socialisation on MSME taxpayer compliance in Bandung City. The results of this study are in line with the research of Hendri (2018), Maulida (2018), Putri \& Nurhasanah (2019), Yudha \& Dewi (2018), that the socialisation of Government Regulation number 23 has a significant effect on MSME taxpayer compliance. The socialisation must be carried out thoroughly, especially to the MSME parties whom Tax Service Offices have not touched.

\section{Tax Understanding and Taxpayer Compliance}

The test results using the t-test obtained significant results of the tax understanding variable of 0.000 , greater than $\alpha=0.05$ and the regression coefficient of 0.315 . It proves a positive and significant influence between the understanding of taxation on MSME taxpayer compliance in Bandung City. The results of this study are in line with research conducted by Febri \& Sulistiyani (2018), Z.A \& Mayowan (2016), Putu \& Cahyani (2019) which states that understanding taxation has a significant influence in influencing the compliance of MSME taxpayers, the more taxpayers feel they understand the tax provisions will be more compliant.

\section{Tax Fairness and Tax Understanding}

The test results using the t-test obtained a significant level of tax justice variable of 0.001 greater than $\alpha=0.05$, and the results of the regression coefficient of 0.297 . It proves a significant and positive influence between tax fairness on the understanding of taxation on MSMEs in Bandung. The results of this study are in line with research conducted by Mei Tan \& Chin-Fatt (2000), Zulhaj (2016), Syaputra (2019), that there is a significant influence between tax justice and understanding of taxation.

\section{Tax Socialisation on Tax Understanding}

The test results using the t-test obtained the level of significance of the tax socialisation variable on tax understanding of 0.000 less than 0.05 and a regression coefficient of 0.136 . It proves that there is a positive and significant influence between the socialisation of taxation on understanding taxation. The results of this study are in line with research conducted by Putra (2020), Suci et al., (2019), Putri \& Nurhasanah (2019) that the socialisation of taxation has a significant effect on understanding taxation, especially among MSMEs with Government Regulation regulation number 23/2018.

\section{Tax Fairness, Tax Compliance and Tax Understanding}

The path analysis and Sobel test results show that tax justice indirectly affects MSMEs taxpayers' compliance through understanding taxation. It can be concluded that the understanding of taxation meets the requirements as an intervening variable or can mediate the effect of tax justice on the compliance of MSMEs taxpayers.

This study's results are in line with research by Yadinta et al. (2018) that justice and understanding of taxes have a positive and significant effect on tax compliance. In line with Musimenta et al. (2017), tax justice begins with tax knowledge about taxation to positively affect tax compliance. One of the tax collection principles put forward by Adam Smith is that tax collection must include the Certainty principle (the principle of legal certainty), where all the things contained in Government Regulation number 23/2018 are a definite legal basis in tax collection. It can be known about the imposition of sanctions, tax subjects, tax objects, the amount of tax to be paid, and payment time. By knowing this, the taxpayer will automatically judge whether the provisions contained in Government Regulation 23 can be categorised as fair or not.

Tax Socialisation, Tax Compliance and Tax Understanding

The path analysis and Sobel test results showed that taxation's socialisation had an indirect effect on MSME taxpayers' compliance through 
understanding taxation with the $\mathrm{t}$ count on the Sobel test greater than the $t$ table, namely 5.167> 1.96. So it can be concluded that the understanding of taxation qualifies as an intervening variable or can mediate tax socialisation on MSME taxpayer compliance.

This study's results align with Putra \& BBN (2020) research, namely, knowledge and understanding have a positive and significant effect on MSME taxpayer compliance. Likewise, the research conducted by (Syaputra, 2019) states that the taxpayer's understanding of Government Regulation 23 positively influences MSME taxpayers' compliance. This research is also supported by (Syaputra, 2019) that the understanding variable is proven to mediate the socialisation of taxpayer compliance. Tax socialisation is carried out to increase taxpayers' knowledge about taxation, in this case, Government Regulation number 23/2018. It is hoped that MSME actors who were not previously taxpayers will be registered as taxpayers and pay taxes. Then taxpayers who were previously noncompliant will become compliant.

\section{Conclusion}

Based on path analysis results, tax fairness does not directly affect the compliance of MSME taxpayers, but indirectly affects MSME taxpayers' compliance through understanding taxation. Meanwhile, tax socialisation directly affects MSME taxpayer compliance, and tax socialisation indirectly affects MSME taxpayer compliance through understanding taxation. Based on the analysis and conclusions results, we suggest that further research can add variables other than in this study that affects MSME taxpayers' compliance in implementing Government Regulation number 23/2018. Furthermore, future research should consider involving more sample. For Tax Service Offices in Bandung, they can work with the Cooperatives and SME Office to socialise more about Government Regulation Number 23/2018.

\section{References}

-, H. (2018). Implementasi Sosialisasi Peraturan Pemerintah No. 23 Tahun 2018 Bagi Pelaku Usaha Mikro, Kecil Dan Menengah (UMKM). Jurnal Vokasi Indonesia, 6(2), 53-58. https://doi.org/10.7454/jvi.v6i2.127

Ajzen, I. (1985). From Intentions to Actions: A Theory of Planned Behavior. In Action Control. https://doi.org/10.1007/978-3-642-69746-3_2

Arviana, N. (2018). Faktor-Faktor Yang Mempengaruhi Kepatuhan Wajib Pajak Orang Pribadi. Jurnal Muara Ilmu Ekonomi Dan Bisnis, 2(1), 146.

https://doi.org/10.24912/jmieb.v2i1.1745

Badan Pusat Statistik. (2018). Potensi Usaha Mikro Kecil Provinsi Jawa Barat. In BPS Provinsi Jawa Barat. https://jabar.bps.go.id/publication/2018/12/31/3f 4fb99d906200ec1f386be5/potensi-usaha-mikrokecil-provinsi-jawa-barat

Dua, S. T. (n.d.). No Title.

Endrianto, W. (n.d.). Prinsip keadilan dalam pajak atas umkm. 6(9), 298-308.

Febri, D., \& Sulistiyani, T. (2018). Pengaruh Pengetahuan dan Pemahaman Peraturan Perpajakan, Penghindaran Pajak dan Sanksi Perpajakan Terhadap Kepatuhan Wajib Pajak (Studi Pada Wajib Pajak Orang Pribadi di Wilayah KPP Pratama Kota Tegal). Permana, 10(1), 15-26.

Gilligan, G., \& Richardson, G. (2005).

Perceptions of tax fairness and tax compliance in Australia and Hong Kong - a preliminary study. Journal of Financial Crime, 12(4), 331-343. https://doi.org/10.1108/13590790510624783

Indriana, M., \& Moh, N. (2020). Tarif Pajak UMKM 0 , 5 \% : Reward Or Punishment?. Jurnal Bisnis Dan Akuntansi, 16(1), 88-100.

Mahadianto, M. Y., \& Astuti, A. D. (2017). Previllage Tax Payer, Sosialisasi Pajak Dan Kepercayaan Pada Otoritas Pajak Terhadap 
Kepatuhan. Jurnal Kajian Akuntansi, 1(1), 7786. https://doi.org/10.33603/jka.v1i1.525

Mangoting, Y., \& Ganis, E. (2015). Developing a Model of Tax Compliance from Social Contract Perspective : Mitigating the Tax Evasion. 211(September), 966-971.

https://doi.org/10.1016/j.sbspro.2015.11.128

Mei Tan, L., \& Chin-Fatt, C. (2000). The Impact of Tax Knowledge on the Perceptions of Tax Fairness and Attitudes Towards Compliance. Asian Review of Accounting, 8(1), 44-58. https://doi.org/10.1108/eb060720

Musgrave, R. A., \& Peggy, M. (1989). Public Finance: In Theory and Practice. Mc Graw Hill Kogakusha.

Ningsih, S. S., Muhammadiyah, U., Utara, S., Saragih, F., Muhammadiyah, U., \& Utara, S. (2020). Jurnal Riset Akuntansi dan Bisnis Jurnal Riset Akuntansi dan Bisnis. 7597(1), 38-44.

Pajak, K. W. (2018). Taxpayer Compliance of Ecotourism Micro Small Medium Enterprises (SMEs) Post Government Regulation No. 23/2018 in Singapadu Village. 23, 958-967.

Putra, A. P. (2020). Anteseden Kepatuhan Wajib Pajak Usaha Mikro, Kecil Dan Menengah. 15(1), 71-90.

Putra, A. P., \& BBN, Y. A. (2020). Anteseden Kepatuhan Wajib Pajak Usaha Mikro, Kecil dan Menengah (Aplikasi PP No 23 Tahun 2018. Jurnal Informasi, Perpajakan, Akuntansi, Dan Keuangan Publik, 15(1), 71. https://doi.org/10.25105/jipak.v15i1.6300

Putri, N. Eka, \& Nurhasanah. (2019). Sosialisasi Pajak, Tingkat Pendidikan dan Sanksi Pajak Terkait dengan Kepatuhan Wajib Pajak UKM (Studi Kasus: Pengusaha UKM Kecamatan Manggar Belitung Timur). 28(02), 213-232.

Putu, L., \& Cahyani, G. (2019). Pengaruh Tarif Pajak, Pemahaman Perpajakan, dan Sanksi EJurnal Akuntansi Universitas Udayana ( Unud), Bali , Indonesia
Rahmawati, A., \& Irianto, G. (2019). Analisis Implementasi Peraturan Pemerintah Nomor 23 Tahun 2018 Mengenai Pajak Penghasilan Final. Jurnal Ilmiah Mahasiswa FEB (JIMFEB), 8(1).

Resmi, S. (2019). Perpajakan: Teori dan Kasus Edisi Revisi. In Salemba Empat.

Sella, N. F., \& Pusposari, D. (2018). Pengaruh Kemudahan Pajak, Keadilan Pajak, dan Sosialisasi Pajak PP Nomor 23 Tahun 2018 Terhadap Kemauan Wajib Pajak UMKM untuk Patuh di Kota Malang. Jurnal Ilmiah Mahasiswa FEB, Universitas Brawijaya.

Suci, T. S. M., Karamoy, H., \& Rondonuwu, S. (2019). Efektivitas Penerapan Peraturan Pemerintah No.23 Tahun 2018 Terhadap Tingkat Pertumbuhan Wajib Pajak Dan Penerimaan PPh Final Pada Kpp Pratama Manado. Going Concern : Jurnal Riset Akuntansi, 14(4), 362370.

https://doi.org/10.32400/gc.14.4.26289.2019

Sugiyono. (2013). Metode Penelitian Pendidikan Pendekatan Kuantitaif, Kualitatif,

Sugiyono. (2018). Metode Penelitian Kombinasi (mixed Methods). In Alfabet.

Sugiyono. (2019). Statistika Untuk Penelitian. Alfabeta.

Susanto, H. (2019). Membangun Kesadaran Dan Kepedulian Sukarela Wajib Pajak. Direktorat Jendral Pajak.

https://www.pajak.go.id/id/artikel/membangun-

kesadaran-dan-kepedulian-sukarela-wajib-pajak

Syaputra, R. (2019). Pengaruh Persepsi Wajib Pajak Atas Penerapan Peraturan Pemerintah Nomor 23 Tahun 2018 dan Pemahaman Perpajakan Terhadap Kepatuhan Wajib Pajak Usaha Mikro, Kecil, Dan Menengah. Jurnal Magister Akuntansi Trisakti, 6(2), 121. https://doi.org/10.25105/jmat.v6i2.5560

T P., Wajib, K., \& Usaha, P. (2016)., Pengaruh Persepsi Wajib Pajak Tentang Penerapan Kecil, Dan Menengah Di Kota Yogyakarta Terhadap,. Jurnal Nominal / Volume V Nomor 2 
Yadinta, P. A. F., Mulyadi, J., \& Suratno.

(2018). Kualitas Pelayanan Fiskus , Dimensi

Keadilan , Kesadaran Wajib Pajak dan

Kepatuhan Wajib Pajak Orang Pribadi. Jurnal

Riset Akuntansi Dan Perpajakan JRAP Vol.,

5(2), 201-212.
Z.A, F. D. P. Z., \& Mayowan, Y. (2016). Pengaruh Pemahaman atas Mekanisme Pembayaran Pajak, Persepsi Tarif Pajak dan Sanksi Pajak terhadap Kepatuhan Wajib Pajak UMKM (Studi Pada Wajib Pajak Yang Terdaftar di KPP Pratama Batu). Jurnal Perpajakan (JEJAK), 10(1), 1-8. 